\title{
The Impact of Regional Trade Agreements on International Trade
}

\author{
Yutaka Kurihara \\ Aichi University, Department of Economics, 1-1 Machihata Toyohashi, Aichi, Japan \\ E-mail: kurihara@vega.aichi-u.ac.jp \\ Received August 31, 2011; revised October 9, 2011; accepted November 9, 2011
}

\begin{abstract}
The gravity model of international trade states that bilateral trade flows based on the economic sizes and distances between two units can be used to examine reasons for international trade. Regional Trade Agreements (RTAs) have appeared recently and have increased markedly in number; however, despite their importance, little study has been performed to analyze the effects of RTAs on international trade. The difference between RTAs and world trade organizations (WTO) is important. Studies of currency integration have appeared recently; however, most assume that currency integration varies the level of international trade between countries by making the proportion constant. This paper eliminates this so-called constant hypothesis and indicates that RTAs alters the slope of the relationship between countries and promote international trade. Empirical analysis indicates that the proportion is not constant. Also, this study shows that RTAs promote international trade more in OECD countries than in non-OECD countries.
\end{abstract}

Keywords: International Trade, Gravity Model, RTAs, WTO

\section{Introduction}

In general, the GATT and WTO have been thought to ensure a level playing field of all, thereby contributing to economic growth and development. However, the proliferation of regional trade agreements (RTAs) in recent decades threatens the future of the multinational trading system because the exclusive trade preference of RTAs, although approved under the provisions of the GATT, are not consistent with an important principle of the multinational trading system, the most favored nation principle, and causes discriminatory trade practices of trade disciplines [1]. RTAs have increased markedly in number and hence have become a very important aspect of the multinational trading system [2].

The gravity model of international trade states that bilateral trade flows are based on the economic sizes (often using GDP) and distance between two units (countries). The model also has been used repeatedly in international relations to examine the effectiveness of currency unions and regional agreements. The model is often extended by including variables to explain language relationships, contiguity, colonial history, exchange rate regimes, and other variables.

The gravity model has been introduced and cited many times. Not only academic fields but also real-world researchers have stated that patterns of trade will be determined by aggregate preferences for goods within countries. [3] stated that if trade encourages greater specialization in production, industry-specific shocks may cause members' business cycles to diverge and that comparative advantages do not predict the relationships in the gravity model. Alternatively, [4] demonstrated that greater trade integration may help correlate national incomes.

[5] showed that the creation of RTAs provides trade preference to member countries to promote bilateral trade. [6] found that expansionary ASEAN + 3RTAs could be a sustainable policy option. [7] demonstrated that the EU may increase trade performance in several industries. [8] showed that pro-labor predictions of the median voter model are supported by the full-fledged FTA. [9] showed that a gravity model suggests that the creation of AFTA, COMESA, and MERCOSUR have increased trade in agriculture between their members. However, [10] showed that RTAs are not an efficient way to promote international trade. On the other hand, there has been little study that has analyzed RTAs using the gravity model in spite of the fact that this model for international trade has been used a lot. One of the reasons is that RTAs are recent phenomenon in the world. 
In these cases, the slope of the bilateral trade-GDP relationship may change when RTAs are adopted. It is very natural to think so. Moreover, to the extent that trade integration encourages greater production specialization, RTAs might permit the exploitation of economies of scale in transportation; information, communication and technology (ICT); and so on, changing the slope of the bilateral trade relationship.

As noted in [11], as existing RTAs are deepened and new ones are being negotiated, it will be important to ensure that trade creation dominates trade diversion. It is therefore essential to examine the effects of RTAs.

This article is organized as follows. The next section shows theoretical analysis on this issue. Section 3 demonstrates the empirical methods and the data used here. Section 4 shows the results and performs additional analysis on the results of previous section. Finally this paper ends with a brief summary.

\section{Theoretical Analysis and Empirical Methodology}

This paper's fixed effect model is similar to [12,13].

$$
\begin{aligned}
\ln \left(\mathrm{TRADE}_{i j t}\right)= & a_{0} \mathrm{RTA}_{i j t}+a_{1} \ln \left(\mathrm{Y}_{i} \mathrm{Y}_{j}\right)+a_{2} \ln \left(\mathrm{PC}_{i} \mathrm{PC}_{j}\right)+ \\
& a_{3} \mathrm{CU}_{i j t}+\mu_{i j}+\varepsilon_{i j t}
\end{aligned}
$$

where $i$ and $j$ are countries (units), TRADE is the value of bilateral trade, RTA is a dummy variable that is unity if countries belong to the same regional trade agreement. $\mathrm{Y}$ is the product of their real GDP, PC is the product of real GDP per capita, CU is a dummy variable that equals one if these countries use the same currency. Finally, $\mu$ is the country-pair fixed effects. $\mu_{i j}$ assumes that $\mu_{i j}=\mu_{j i}$; the fixed effects do not depend on the direction of international trade. Panel data for all over the world is used except for missing cases.

RTAs nonlinear effects may arise as a result of selection into agreements for international trade by countries that tend to be small, poor, and remote. The impact of a change in RTA condition or slope coefficient is examined in the next section.

I used the panel data for OECD and non-OECD countries. The sample data are from 1985 to 2009. All the data are yearly. RTAs and member countries were obtained from the membership of proliferation of regional trade agreements by the WTO. All other data are from International Financial Statistics (IMF), World Development Indicators (World Bank). Finally, if there were insignificant variable(s), I omitted this (these) variable(s), estimated again, and computed the RTAs' effects on international trade

\section{Estimated Results and Revised Estimation}

The results of Equation (1) are shown in Table 1.
The results are almost as expected. Columns (1) and (4) in Table 1 show that the estimated coefficient for RTA is 0.815 (OECD) and 0.798 (non-OECD). Both are positive and significant. RTAs certainly promote international trade. It is interesting to note that the effect is bigger for OECD countries than for non-OECD countries.

The effects of nonlinear RTAs may arise as explained in the previous section. Next, quadratic terms of $\ln \left(\mathrm{Y}_{i} \mathrm{Y}_{j}\right)$ and $\ln \left(\mathrm{PC}_{i} \mathrm{PC}_{j}\right)$ are added as in [13], for the case of currency integration. The results are in columns (2) and (5), which demonstrates that both variables are positive and significant and confirms nonlinearity. The analysis is performed later.

I investigated the impact of a change in the condition of the RTAs by adding the following interaction terms: 1) RTA and $\ln \left(\mathrm{DIST}_{i j}\right)$, where $\mathrm{DIST}_{i j}$ is the distance between countries, 2) RTA and $\ln \left(Y_{i} Y_{j}\right)$, and 3) RTA and $\ln \left(\mathrm{YPC}_{i} \mathrm{YPC}_{j}\right)$. The quadratic terms and the interaction term of RTA and $\ln \left(\mathrm{Y}_{i} \mathrm{Y}_{j}\right)$ are significant at the $1 \%$ level; the introduction of RTAs changes the relationship between trade and GDP in OECD and non-OECD countries. On the other hand, the changes in relationships between trade and GDP per capita and trade and distance are not significant.

It is interesting to note that the relationship between international trade and distance is insignificant in OECD countries; however, they also are significant in nonOECD countries. As transportation system and ICT improve, the effect of distance on international trade may decrease. In OECD countries, distance is still an important factor in the promotion of international trade.

I excluded the insignificant variables and computed the effect of the RTAs. The calculation equation is as follows [13]:

$$
\mathrm{RTAEFFECT}_{i j t}=\exp \left(a_{\mathrm{RTA}}+a_{\mathrm{RTA} \times \ln \left(Y_{i} Y_{j}\right)} \ln \left(Y_{i} Y_{j}\right)\right)-1
$$

The equations shows how the RTAs effects (RTAEF$\mathrm{FECT}_{i j t}$ ) are distributed where both countries are members of the same RTAs (i.e., $\mathrm{RTA}_{i j t}=1$ ). The results are 0.780 for OECD and 0.713 for non-OECD countries.

There is high possibility that RTAs do not reduce bilateral trade if a large country is involved. However, it should be noted that although some country pairs experience substantially higher levels of trade when they share a common RTAs, for a significant subset of country pairs, members of RTAs are associated with a lower level of bilateral trade. How RTAs promote international trade depends on the constitution of the pair of countries. RTAs surely promote international trade; however, the proportion is not necessarily proportional. Each country should consider this fact and use it effectively to gain 
Table 1. Estimated results for gravity model of international trade.

\begin{tabular}{|c|c|c|c|c|c|c|}
\hline & \multicolumn{3}{|c|}{ OECD } & \multicolumn{3}{|c|}{ Non-OECD } \\
\hline & (1) & (2) & (3) & (4) & (5) & (6) \\
\hline RTA & $\begin{array}{l}0.815^{* * *} \\
(20.125)\end{array}$ & $\begin{array}{l}0.740^{* * * *} \\
(19.999)\end{array}$ & $\begin{array}{l}0.731^{* * *} \\
(19.351)\end{array}$ & $\begin{array}{l}0.798^{* * *} \\
(18.530)\end{array}$ & $\begin{array}{l}0.722^{* * *} \\
(18.023)\end{array}$ & $\begin{array}{l}0.725^{* * *} \\
(18.150)\end{array}$ \\
\hline $\ln \left(Y_{i} Y_{j}\right)$ & $\begin{array}{l}0.456^{* * *} \\
(30.126)\end{array}$ & $\begin{array}{l}0.412^{* * *} \\
(27.652)\end{array}$ & $\begin{array}{l}-3.010 \\
(-1.202)\end{array}$ & $\begin{array}{l}0.470^{* * *} \\
(29.319)\end{array}$ & $\begin{array}{l}0.444^{* * *} \\
(24.873)\end{array}$ & $\begin{array}{c}-2.904 \\
(-1.105)\end{array}$ \\
\hline $\ln \left(\mathrm{PC}_{i} \mathrm{PC}_{j}\right)$ & $\begin{array}{l}0.530^{* * *} \\
(9.182)\end{array}$ & $\begin{array}{l}0.602^{* * *} \\
(9.937)\end{array}$ & $\begin{array}{c}-0.685 \\
(-0.973)\end{array}$ & $\begin{array}{c}0.541^{* * *} \\
(9.362)\end{array}$ & $\begin{array}{l}0.610^{* * * *} \\
(9.948)\end{array}$ & $\begin{array}{c}-0.623 \\
(-0.451)\end{array}$ \\
\hline CU & $\begin{array}{l}0.535^{* * *} \\
(4.883)\end{array}$ & $\begin{array}{l}0.560^{* * *} \\
(5.100)\end{array}$ & $\begin{array}{l}-1.630 \\
(-1.067)\end{array}$ & $\begin{array}{l}0.535^{* * *} \\
(4.883)\end{array}$ & $\begin{array}{l}0.605^{* * *} \\
(5.918)\end{array}$ & $\begin{array}{c}-1.432^{* *} \\
(-2.067)\end{array}$ \\
\hline $\ln \left(Y_{i} Y_{j}\right)^{2}$ & & $\begin{array}{l}0.035^{* * *} \\
(9.187)\end{array}$ & $\begin{array}{c}0.088^{* * *} \\
(11.258)\end{array}$ & & $\begin{array}{l}0.039^{* * *} \\
(9.392)\end{array}$ & $\begin{array}{c}0.0899^{* * * *} \\
(13.458)\end{array}$ \\
\hline $\ln \left(\mathrm{PC}_{i} \mathrm{PC}_{j}\right)^{2}$ & & $\begin{array}{l}0.059^{* * * *} \\
(6.352)\end{array}$ & $\begin{array}{l}0.058^{* * * *} \\
(6.234)\end{array}$ & & $\begin{array}{l}0.063^{* * * *} \\
(6.438)\end{array}$ & $\begin{array}{l}0.060^{* * * *} \\
(5.922)\end{array}$ \\
\hline $\mathrm{RTA}^{*} \ln \left(\mathrm{Y}_{i} \mathrm{Y}_{j}\right)$ & & & $\begin{array}{l}0.125^{* * *} \\
(4.624)\end{array}$ & & & $\begin{array}{l}0.143^{* * * *} \\
(5.082)\end{array}$ \\
\hline $\mathrm{RTA}^{*} \ln \left(\mathrm{PC}_{i} \mathrm{PC}_{j}\right)$ & & & $\begin{array}{c}-0.070 \\
(-0.770)\end{array}$ & & & $\begin{array}{c}-0.055 \\
(-0.342)\end{array}$ \\
\hline $\mathrm{RTA}^{*} \ln \left(\mathrm{DIST}_{i j}\right)$ & & & $\begin{array}{c}0.150 \\
(0.372)\end{array}$ & & & $\begin{array}{l}0.333^{* * *} \\
(6.080)\end{array}$ \\
\hline RTAs effect & 0.801 & 0.680 & 0.823 & 0.821 & 0.693 & 0.844 \\
\hline Adj. $R^{2}$ & 0.789 & 0.812 & 0.818 & 0.725 & 0.756 & 0.704 \\
\hline DW & 1.898 & 1.903 & 1.912 & 1.822 & 1.844 & 1.876 \\
\hline
\end{tabular}

Note: Numbers in parentheses are t statistics. ${ }^{* * * *}$ Denotes significant at $1 \%,{ }^{* *}$ at $5 \%$, and ${ }^{*}$ at $10 \%$ level.

from international trade.

\section{Conclusions}

I have provided evidence regarding the need to account for slope effects when specifying gravity models to estimate the impact of RTAs on bilateral trade. RTAs promote international trade more in OECD countries than non-OECD countries. Finally, for the results of distribution of RTAs effects, it should be noted that the potentials for RTAs are different. Whether and how RTAs promote bilateral trade depends on the constitution of the countries involved.

There is some room yet for further study, however. I treated the RTAs the same way in all cases; however, there are large differences among them. The content is different in each case. Also, the relationship between RTAs and WTO should be examined deeply and carefully. To ensure that RTAs do not undermine the multilateral trading system, the WTO can oversee them by using its political judicial review procedures. There is likely to be some differences between developed, developing, and emerging countries. To focus on these issues, for example, would be interesting. Finally, as RTAs have developed recently, the sample period is too short to in- vestigate it adequately. Time is needed for analyses. Further research is needed in this field.

\section{Acknowledgements}

I thank an anonymous referee for the comments and suggestions.

\section{References}

[1] Y. Lee, "Reconciling RTAs with the WTO Multinational Trading System: Case for a New Sunset Requirement on RTAs and Development Facilitation," Journal of World Trade, Vol. 45, No. 3, 2011, pp. 629-651.

[2] J. Varzary, "The Failure of Regional and Multinational Trade Agreements,” The Business Review, Vol. 17, No. 1, 2011, pp. 235-240.

[3] P. Krugman, “Lessons of Massachusetts for EMU,” In: F. Glavazzi and F. Torres, Eds., The Transition to Economic and Monetary Union in Europe, Cambridge University Press, New York, 2001, pp. 241-261.

[4] R. Baldwin, “The Euro’s Trade Effects,” Working Paper, 594, European Central Bank, Hesse, 2006.

[5] V. Vicard, "On Trade Creation and Regional Trade Agreements: Does Depth Matter?” Review of World Economics, Vol. 145, No. 2, 2009, pp. 167-187. 


\section{doi:10.1007/s10290-009-0010-9}

[6] I. Park, "Regional Trade Agreements in East Asia: Will They Be Sustainable?” Asian Economic Journal, Vol. 23, No. 2, 2009, pp. 169-194.

doi:10.1111/j.1467-8381.2009.02008.X

[7] Y. Decreux, C. Milner and N. Peridy, "Some New Insights into the Effects of the EU-South Korea Free Trade Area: The role of Non-Tariff Barriers,” Journal of Economic Integration, Vol. 25, No. 4, 2010, pp. 783-817.

[8] L. Xuepeng, “Testing Conflicting Political Economy Theories: Full-Fledged Partial-Scope Regional Trade Agreements,” Southern Economic Journal, Vol. 77, No. 1, 2010, pp. 78-103. doi:10.4284/sej.2010.77.1.78

[9] J. Korinek and M. Melatos, "Trade Impacts of Selected Regional Trade Agreements in Agriculture," OECD Trade Policy Working Paper, No. 87, 2009.
[10] A. Vamvakidis, "Regional Trade Agreement or Broad Liberalization: Which Path Leads to Faster Growth?" IMF Economic Review, Vol. 46, No. 1, 1999, pp. 42-52.

[11] S. Coulibaly, "Evaluating the Trade Effect of Developing Regional Trade Agreements: A Semi-Parametric Approach," Journal of Economic Integration, Vol. 24, No. 4, 2009, pp. 709-743.

[12] R. A. Frankel and A. Rose, "The Endogeneity of the Optimum Currency Area Criteria,” The Economic Journal, Vol. 108, No. 449, 1998, pp. 1009-1025. doi:10.1111/1468-0297.00327

[13] H. Katayama and M. Melatos, "The Nonlinear Impact of Currency Unions on Bilateral Trade,” Economics Letters, Vol. 112, No. 1, 2011, pp. 94-96. doi:10.1016/j.econlet.2011.03.022 